\title{
Mengembangkan Pelayanan Pendampingan Pastoral Kepada Lanjut Usia di Gereja HKBP Letare Ciledug
}

\author{
Romantoh Sibarani \\ Mahasiswa Pascasarjana Sekolah Tinggi Teologi Sriwijaya \\ lissonsibarani91@gmail.com
}

\begin{abstract}
This research is intended to give attention to aged members of the church at the HKBP Letare Ciledug. HKBP Letare Ciledug is only 11 years old, but many of it's members are aged. Seen from an increasingly old age, physical and mental conditions that are declining, experiencing many crises and problems. The aged crave their attention of those closest to them, especially from the church. The authors conducted research and want to provide service through pastoral assistance that is sustaining and nurturing. The function of sustaining is to help aged people who are sick or injured in order to survive overcoming the conditions experienced. Function of nurturing is to help the aged develop the potential given by God to overcome the problems. Sampling was carried out for five aged members of the church at the HKBP Letare Ciledug. The five members of the congregation interviewed represented the aged congregation, having different struggles and problems, but had the same problem: limited mobility and activity due to illness and an aging body. This struggle has not been touched by Church service. With pastoral care services, through sustaining and nurturing, which is done in the form of Group Counseling, by : Ministry of Word and Sacrament, Sermons, Prayer and Worship, able to help aged to mature and accept their life problems. In the future, church services to the aged will develop and advance in the church of HKBP Letare Ciledug.
\end{abstract}

Key words: elder, pastoral care, sustaining and nurturing, relevant pastoral care

\begin{abstract}
Abstrak: Penelitian ini dimaksudkan untuk memberikan perhatian kepada warga jemaat yang lanjut usia di gereja HKBP Letare Ciledug. Gereja HKBP Letare baru berusia 11 tahun, tetapi banyak warga jemaatnya yang sudah berusia lanjut. Dilihat dari usia yang semakin tua, kondisi fisik dan mental yang semakin menurun, mengalami banyak krisis dan permasalahan. Para lanjut usia mendambakan perhatian dari orang-orang terdekatnya, terutama dari gereja. Berdasarkan hal inilah saya melakukan penelitian dan ingin memberikan pelayanan melalui pendampingan pastoral yang bersifat menopang dan memelihara atau memberdayakan. Fungsi menopang adalah menolong lanjut usia yang sakit atau terluka agar dapat bertahan dan merngatasi keadaan yang dialami. Fungsi memelihara atau memberdayakan adalah menolong lanjut usia mengembangkan potensi-potensi yang diberikan Allah kepadanya untuk mengatasi masalah yang dihadapinya. Pengambilan sampel dilakukan kepada lima orang warga jemaat lanjut usia di gereja HKBP Letare Ciledug.Kelima warga jemaat yang diwawancarai ini mewakili jemaat lanjut usia, mempunyai pergumulan dan permasalahan yang berbeda-beda, tetapi memiliki persoalan yang sama yaitu: terbatasnya gerak dan aktivitas karena penyakit dan tubuh yang menua. Pergumulan ini belum tersentuh oleh pelayanan Gereja, karena Gereja lebih banyak disibukan oleh pelayanan ibadah dan rutinitas persekutuan. Dengan pelayanan pendampingan pastoral, melalui penopangan dan pemberdayaan, yang dilakukan dalam bentuk Konseling Kelompok berupa: pelayanan Firman dan Sakramen, Khotbah, Doa dan Ibadah diharapkan mampu menolong lanjut usia untuk semakin dewasa menerima dan mengatasi permasalahan hidup mereka. Ke depannya pelayanan gereja kepada lanjut usia semakin berkembang dan maju di gereja HKBP Letare Ciledug. Metode penelitian dilakukan dengan wawancara secara langsung kepada konseli dengan seijin mereka.
\end{abstract}

Kata Kunci: lanjut usia, pelayanan pastoral, menopang dan memelihara, pelayanan pastoral yang relevan.

Article History

\begin{tabular}{|l|l|l|}
\hline Submitted: 3 Juli 2020 & Revised: 13 Desember 2020 & Accepted: 31 Desember 2020 \\
\hline
\end{tabular}




\section{PENDAHULUAN}

Orang tua adalah anugerah Tuhan di dalam keluarga, tanpa adanya mereka kita tidak akan ada di dunia ini. Ketika anak-anaknya masih kecil, orang tua berjuang keras dengan segala daya dan upaya membesarkan, memberikan pangan dan pendidikan yang layak. Hingga tidak jarang orang tua tidak memerdulikan, rasa lelah, panas teriknya matahari serta sakit yang mereka alami demi anak-anaknya. Segala sesuatu mereka lakukan untuk memerjuangkan hidup dan masa depan anakanaknya.Pada saat sudah tua, mereka sudah tidak lagi berdaya dan tidak bisa sesehat sebelumnya, tidak bisa berbuat apa-apa lagi karena fisiknya sudah lemah, banyak diantara anak-anaknya yang malah mengabaikannya. Anak-anak beralasan tidak memiliki waktu karena sibuk dengan pekerjaan sehingga orang tua digilir tinggal di rumah anak-anak dan kadang dirawat oleh pembantu. Mereka merasa kesepian karena ditinggal atau berpisah dengan anak-anak atau keluarga dekatnya.Gereja sering melupakan dan mengabaikan keberadaan lanjut usia. Gereja hanya disibukkan sekitar pelayanan persekutuan dan kebaktian. Gereja sepatutnya ikut bertanggung jawab ambil bagian dalam pelayanan pengembalaan kepada kaum lanjut usia. Banyak pelayanan yang bisa dilakukan baik melalui pengembalaan, perkunjungan rutin, konseling, pendampingan kepada lanjut usia itu sendiri, atau mendirikan badan diakonia yang khusus melayani kaum lanjut usia.

Melalui tulisan ini saya melihat pentingnya pendampingan pelayanan kepada lanjut usia untuk menjawab pergumulan dan permasalahan yang mereka hadapi di masa tua mereka. Lanjut usia perlu di dampingi supaya mereka dapat menolong dan memampukan diri mereka sendiri mengatasi setiap permasalahan yang mereka hadapi, dapat meningkatkan kemampuan menjalin hubungan dengan orang lain dan meningkatkan kemampuan serta mengembangkan potensi-potensi yang diberikan Allah kepada mereka.

\section{METODE PENELITIAN}

Penulis akan menggunakan metodologi penelitian wawancara terhadap lima orang lanjut usia di Gereja HKBP Letare Ciledug. Penulis juga akan menggunakan penelitian literatur untuk memperkuat kajian tinjauan terhadap narasumber. 


\section{HASIL DAN PEMBAHASAN}

\section{Mengenal Lanjut Usia dan keberadaanya}

Lanjut usia adalah suatu keadaan yang ditandai oleh gagalnya seseorang dalam mempertahankan keseimbangan terhadap kesehatan dan kondisi stress fisiologis. Lanjut usia adalah salah satu fase kehidupan manusia yang tidak boleh tidak harus dihadapi. Proses penuaan tersebut adalah alamiah dan normal. Usia lanjut adalah menurunnya secara berangsur-angsur sistem organis manusia menuju kepada akhir kehidupan dan kematian (Williamson, 1987). Proses penuaan merupakan siklus perkembangan pertumbuhan mulai dari lahir, anak-anak, dewasa, orang tua hingga usia lanjut/tua. Semakin tua, terjadi proses penurunan daya kemampuan untuk hidup dan kepekaan secara individual. Jadi masa tua adalah masa paling akhir dari siklus kehidupan manusia.

Badan Kesehatan Dunia (WHO) menetapkan usia 65 tahun sebagai usia yang menunjukkan proses penuaan yang berlangsung secara nyata dan seseorang telah disebut lanjut usia. Selanjutnya WHO menggolongkan lanjut usia menjadi 4 golongan yaitu:

- Usia pertengahan (middle age) 45 - 59 tahun

- Lanjut usia (aged) 60 - 74 tahun

- Lanjut usia tua (old) 75 - 89 tahun

- Lanjut usia sangat tua (very old) di atas 90 tahun.

Hurlok Elizabeth (Elizabeth, 1992) menyebutkan beberapa ciri-ciri orang lanjut usia yaitu:

1. Usia lanjut merupakan periode kemunduran.

Pada masa ini mereka mulai mengalami kemunduran bertahap yang disebut dengan 'menua'. Perubahan tersebut meliputi fisik, mental maupun psikologis.

2. Orang lanjut usia memiliki status kelompok minoritas.

Status kelompok minoritas ini terjadi akibat dari sikap sosial yang tidak menyenangkan terhadap lanjut usia dan diperkuat oleh pendapat klise yang tidak menyenangkan terhadap mereka, sehingga mereka disebut sebagai "warga negara kelas dua."

3. Menua membutuhkan perubahan peran.

Lanjut usia sering dianggap tidak berguna lagi. Hal ini mengakibatkan pengurangan jumlah kegiatan yang dapat dilakukan oleh lanjut usia. Karenanya perlu mengubah beberapa peran yang masih dilakukan, sebaiknya dilakukan atas dasar keinginan sendiri bukan atas dasar tekanan dari lingkungan. 
4. Penyesuaian yang buruk pada lanjut usia.

Ini terjadi karena semakin hilangnya status karena kegiatan sosial didominasi oleh orang-orang yang lebih muda, menyebabkan orang-orang pada usia lanjut cenderung buruk dalam menyesuaikan diri.

Maria Bons-Strom, seorang doktor psikologi menyebutkan bagaimana keadaan orang yang sudah tua (Bons-Strom, 2015). la menyimpulkan keadaannya adalah begini:

1. Kesehatannya kurang baik.

2. Merasa dikucilkan dari kesibukan dalam hubungan masyarakat.

3. Merasa kesepian, sehingga banyak berpikir dan merenung.

4. Hubungan dengan teman-temannya seumur, yang betul-betul mengerti keadaan mereka yang sudah tua, adalah kurang sekali.

5. Mereka sering menggumuli maut yang makin hari semakin dekat.

Dari pemahaman di atas kita melihat bahwa masa lanjut usia adalah masa yang penuh dengan persoalan dan tantangan yang harus dijalani. Masalah kesehatan, hidup kesepian karena ditinggal anak-anak, perubahan pekerjaan adalah beberapa persoalan yang kompleks dialami oleh lanjut usia. Masalah kesehatan merupakan masalah yang paling banyak dialami saat usia lanjut

\section{Tantangan dan Pergumulan Lanjut Usia}

\section{Ditinjau Secara Fisik}

Secara umum masalah yang dihadapi lanjut usia berkaitan dengan kesehatan fisik yaitu berkurangnya daya tahan tubuh dalam menghadapi pengaruh dari luar, menderita berbagai penyakit yang berhubungan dengan ketuaan antara lain; diabetes miletus, hipertensi, jantung koroner, rematik dan asma. Berbagai penyakit ini menyebabkan aktivitas bekerja lanjut usia menjadi terganggu.Semakin tua tubuh semakin melemah dan makin banyak penyakit yang datang, daya tahan dan konsentrasi semakin berkurang. Berdiri, berjalan dan bergerak semakin melelahkan, mudah merasa lelah. Timbullah gejala-gejala penuaan, yang makin lama makin berat; seperti otot-otot yang mulai melemah, organ-organ dan otak sudah mulai kurang baik melayani. Pencernaan sudah mulai bermasalah dan lain-lain, muncullah kekawatiran, bahwa semuanya semakin menyusut dan menurun.Penurunan kondisi fisik sering berjalan dengan peningkatan atau pertambahan usia yang mengakibatkan kemampuan kerja dan kegiatan menurun. Semua organ di dalam tubuh kita 
mengalami penuaan, sehingga terjadi perubahan atau kemunduran fungsi-fungsinya. Hal ini dijelaskan oleh Hana Santoso (seorang dokter perintis panti Werda Kristen Hana Ciputat) dan Andar Ismail dalam buku "Memahami Krisis Lanjut Usia" yang menyebutkan beberapa kemunduran atau perubahan fungsi pada lanjut usia antara lain (Santoso \& Ismail, 2016):

\section{a. Sistem Pencernaan.}

Ada perubahan fungsi yang terjadi pada saluran cerna orang lanjut usia. Makanan mulai sulit dikunyah karena gigi sudah mulai ompong, air liur menjadi lebih kental karena berkurangnya produksi kelenjar-kelenjar liur. Selera makan lanjut usia menjadi berkurang dengan jumlah konsumsi makanan yang sedikit.

\section{b. Sistem Pernafasan.}

Pada lanjut usia, daya tahan tubuh sudah melemah dan produksi antibodi (zat untuk melawan racun bakteri) juga sudah menurun sehingga mereka sangat rentan terhadap infeksi paru-paru, mudah terkena sakit flu, batuk, radang paru-paru, dan lain-lain.

\section{c. Jantung dan Pembuluh Darah.}

Pada proses penuaan, jantung mengalami hipertrofi (pembesaran karena sel-sel otot jantung membesar), padahal organ-organ lain mengalami penciutan atau pengecilan. Dinding kamar jantung menebal, katup-katup jantung menebal dan kaku, sehingga daya pompa otot jantung menurun dan para lansia merasa cepat lelah dan mengeluh sesak nafas jika berjalan jauh dan menaiki anak tangga. Dinding pembuluh darah juga mengalami penebalan dan pengerasan sehingga menjadi kaku.

\section{d. Fungsi Ginjal dan Kandung Kemih.}

Pada proses penuaan, fungsi ginjal menurun, karena berat ginjal berkurang dari 250 gram menjadi sekitar 180 gram sebagai akibat hilangnya jaringan jaringan penunjang dan berkurangnya unit-unit terkecil ginjal, sehingga kemampuan ginjal berkurang dan fungsi ginjal juga menurun. Ini mengakibatkan lanjut usia mengeluh sering buang air kecil dan sulit menahan keinginan pipis sehingga terpaksa "ngompol" karena kapasitas kandung kemih sudah berkurang.

\section{e. Panca Indra.}

Gangguan penglihatan dan pendengaran merupakan masalah penting yang menyertai lanjut usia. Dengan berkurangnya penglihatan, lanjut usia sering kehilangan rasa percaya diri, berkurangnya keinginan untuk pergi ke luar, dan malas untuk bergerak. Pendengaran adalah kesehatan mental yang krusial bagi lanjut usia. Kehilangan pendengaran jauh lebih banyak efeknya dari penglihatan. Dengan menurunnya pendengaran, ada dampaknya dalam hubungan sosial dengan orang lain, yaitu 
mereka menjadi sulit berkomunikasi dengan lancar. Indra pengecap dan pencium juga berkurang sehingga nafsu makan berkurang. Kulit menjadi kering dan keriput sehingga lansia sering mengeluh gatal di sekujur tubuh. Kuku menjadi kaku dan tebal, rambut menipis karena banyak yang rontok, uban senantiasa bertambah, sedangkan yang tumbuh sedikit. Penurunan fungsi pancaindra menyebabkan lanjut usia merasa rendah diri, mudah tersinggung dan bahkan merasa tidak berguna.

\section{f. Berkurangnya Produksi Hormon.}

Penurunan fungsi dan potensi seksual pada lanjut usia seringkali berhubungan dengan berbagai gangguan fisik seperti gangguan jantung dan metabolisme. Disfungsi seksual karena perubahan hormonal atau masalah kesehatan jiwa lainnya, misalnya, cemas, depresi, pikun dan sebagainya. Pada sebagian wanita mudah tersinggung, cepat marah, suasana hati gampang berubah-ubah, mudah panik, merasa tidak berguna, kecewa, sedih dan emosi tidak stabil. Pada kaum pria kadar hormone testosterone mulai menurun mengakibatkan menurunya minat seksual, frekuensi impotensia meningkat, otot menjadi lembek, energi dan kekuatan juga berkurang.

Menyikapi penurunan kondisi fisik, dalam kehidupan lanjut usia agar tetap menjaga kondisi fisik yang sehat, maka perlu menyelaraskan kebutuhan-kebutuhan fisik dengan kondisi psikologi maupun sosial, sehingga mau tidak mau harus ada usaha untuk mengurangi kegiatan yang memporsir fisiknya. Seorang lanjut usia harus mampu mengatur cara hidup yang baik misalnya makan, tidur, istirahat dan bekerja dengan seimbang.

\section{Tinjauan dari Sudut Psikologis.}

Kemunduran psikologis yang dialami lanjut usia lebih disebabkan oleh penerimaan akan situasinya pada saat ini, relasi dan pandangan terhadap orang lain, pekerjaan dan situasi lainnya, yang dapat mempengaruhi fisik, mental dan sosial. Usia lanjut secara psikologis berhubungan dengan perubahan-perubahan dalam kapasitas beradaptasi maupun berperilaku terhadap pengalaman yang lebih luas. Lanjut usia mengalami penurunan fungsi kognitif dan psikomotorik. Fungsi kognitif meliputi proses belajar, persepsi, pemahaman, pengertian, perhatian dan lain-lain. Penurunan fungsi kognitif menyebabkan reaksi dan perilaku lanjut usia makin lambat. Fungsi psikomotorik meliputi hal-hal yang berhubungan dengan dorongan kehendak seperti gerakan, tindakan dan koordinasi. Penurunan fungsi psikomotorik mengakibatkan 
lanjut usia menjadi kurang cekatan. Kondisi fisik yang menurun berpengaruh pada kondisi psikis.

Perubahan kondisi fisik yang dialami lanjut usia mempengaruhi juga kepada kondisi psikologisnya. Lanjut usia sering merasa rendah diri, mudah merajut dan putus asa. Pada sebagian wanita mudah tersinggung, cepat marah, suasana hati gampang berubah-ubah, merasa tertekan, murung, sedih, kecewa, merasa tidak berguna, mudah panik, mudah lupa, konsentrasi buruk dan emosi tidak stabil. Semua ini terjadi karena penurunan kadar hormon yang mempengaruhi keadaan psikologis wanita menjelang menopause (Santoso \& Ismail, 2016).

Kesepian membuat lanjut usia merasa seolah-olah terkurung dalam rumahnya, karena kelemahan badan dan disingkirkan dari kesibukan dalam masyarakat. Keadaan ini bisa menimbulkan masalah psikologi yang besar. Lagi pula seorang lakilaki maupun perempuan tidak mudah menerima diri sebagai single. Oleh karena itu janda dan duda lanjut usia dipaksa untuk mencari persekutuan lain. Karena bagi para lanjut usia kontak dengan teman-teman seumur sangat tinggi nilainya. Mereka dapat bertukar pikiran dan bercakap-cakap tentang masa lalu, ketika mereka masih muda dan kuat, ketika masih efektif berperan dalam masyarakat.

Kondisi lain pada usia lanjut adalah terjadinya penurunan mental yang menyertai bertambahnya usia. Perubahan mental ini mempengaruhi beberapa hal, antara lain: proses belajar, berpikir dalam memberi argumentasi, kreativitas, ingatan, mengingat kembali, mengenang, rasa humor, perbendaharaan kata dan kekerasan mental (Elizabeth, 1992).

\section{Tinjauan dari Kondisi Ekonomi.}

Pada umumnya lanjut usia mengalami perubahan atau penurunan kondisi ekonomi. Ini disebabkan karena lanjut usia sudah tidak bekerja lagi dan menurunnya produktivitas kerja dan terbatasnya kesempatan kerja. Kemiskinan menjadi ancaman kesejahteraan terbesar bagi lanjut usia sebab pendapatan rendah, kesehatan dan gizi buruk serta akses terhadap pelayanan dasar berkurang. Kondisi ekonomi lanjut usia menurun karena sudah memasuki masa pensiun bagi yang pegawai.

Karena kondisi ekonomi juga membuat para lanjut usia cenderung menarik diri dari lingkungannya. Sebagaimana dikatakan oleh Becker karena kondisi ekonomi para lanjut usia tidak menghadiri kegiatan gereja dengan frekuensi yang lebih besar, karena merasa tidak cukup pakaian untuk dipakai, tidak cukup uang untuk persembahan (Becker, 1986). Faktor ekonomi juga berkaitan dengan ketidaksanggupan mereka 
bekerja sama dan mengikuti kelompok sosial. Tekanan ekonomi membuat mereka terisolasi dan tereliminasi, sehingga dalam kondisi ini dukungan komunitas, keluarga dan jemaat menjadi amat penting.

\section{Tinjauan dari Sudut Sosial Budaya.}

Sebagai makhluk sosial, manusia memiliki motif untuk mengadakan hubungan dan hidup dengan orang lain dalam rangka memenuhi kebutuhan dasar yang disebut dengan dorongan sosial. Sebagai makhluk individual memiliki motif untuk mengadakan hubungan dengan diri sendiri. Kehidupan manusia sebagai makhluk sosial selalu dihadapkan kepada masalah sosial yang tidak dapat dipisahkan dalam kehidupan. Sementara kebudayaan adalah suatu keseluruhan kompleks yang meliputi pengetahuan, kepercayaan, kesenian, moral, keilmuan, hukum, adat-istiadat dan kemampuan yang lain serta kebiasaan yang didapat oleh manusia sebagai anggota keluarga dan masyarakat, unsur-unsur sosial budaya ini tersebar dan meliputi banyak kegiatan sosial manusia. Kehidupan lanjut usia termasuk di dalamnya.

Ada beberapa perubahan kondisi sosial yang dialami oleh lanjut usia, antara lain :

1. Meninggalnya pasangan hidup sehingga lanjut usia menjadi duda/janda.

2. Anak-anak yang dimiliki telah dewasa dan membentuk keluarga sendiri.

3. Berkurangnya teman atau relasi akibat dari berkurangnya aktifitas/kegiatan di luar rumah maupunkarena teman hidup lebih dahulu meninggal dunia.

4. Berkurangnya kegiatan/aktifitas sehingga waktu luang bertambah banyak.

5. Berkurangnya rasa ketergantungan baik karena kemunduran fisik/mental yang dialami maupun karena alasan ekonomi.

\section{Tinjauan dari Sudut Spiritualitas.}

Kebutuhan spiritual merupakan salah satu kebutuhan dasar manusia untuk mencari tujuan dan harapan hidup, yang di dalamnya ada kedamaian, ketenangan, cinta, kasih sayang, bersyukur dan keyakinan. Sebagian besar lanjut usia mengisi hari-hari hidupnya dengan kegiatan keagamaan dan ibadah persekutuan. Dengan meleburkan dirinya dalam kegiatan keagamaan mereka mendapatkan kedamaian jiwa, ketenangan dan relasi dengan Tuhan.Para lanjut usia menghabiskan hari-hari hidupnya dengan ambil bagian di dalam persekutuan dan pelayanan di gereja. Di dalam persekutuan lansia di gereja, mereka dapat mencurahkan isi hatinya, perasaannya tentang pengalaman hidup, kesedihan, kesepian dan keluarga. Ibadah persekutuan telah menciptakan hubungan yang akrab dan erat di antara sesama lanjut 
usia untuk saling mengasihi dan berbagi, serta ikuit ambil bagian dan peran dalam pelayanan gereja.

\section{Potensi, Kedudukan dan Peran Lanjut Usia}

Orang lanjut usia bukan sekedar lanjut usia yang tua, yang tidak berdaya, yang mempunyai banyak kelemahan dan kekurangan karena semakin bertambahnya usia, tetapi mereka adalah lanjut usia yang tua, tetapi sekaligus mempunyai potensi, kedudukan dan peran, baik di dalam gereja, keluarga dan masyarakat. Beberapa potensi, peranan dan kedudukan lanjut usia, antara lain:

\section{a. Di Gereja:}

1. Lanjut usia sebagai panutan, teladan dan penasehat (Ayub 15: 10; 1 Raja-raja 12: 6,8). Peranan lanjut usia dalam hal ini adalah memberikan teladan sebagai orang tua yang memiliki pengalaman, terlebih pengalaman iman maupun pengalaman membina keluarga.

2. Lanjut usia sebagai partisipator di dalam gereja. Untuk meningkatkan pertumbuhan gereja, maka partisipasi dari lanjut usiamenjadi penyokong dalam membina hubungan kerjasama di dalam gereja.

3. Lanjut usia sebagai pengikat kesatuan. Secara tidak sadar, keberadaan mereka sebagai pengikat kesatuan antara warga jemaat, di dalam gereja. Pengikat kesatuan berarti pengikat hubungan kerjasama kepada sesama lanjut usia; saling berbagi info seputar pengalaman hidup dan saling memberikan dukungan dalam penataan masa depan, khususnya di dalam pembinaan spiritual dan ekonomi.

4. Lanjut usia sebagai manusia yang potensial. Mereka memberi kemampuan dan pengalaman profesional yang langka untuk didayagunakan di dalam gereja. Hal inilah yang perlu diperhatikan di dalam gereja dengan tidak mengabaikan peran lanjut usia untuk terus berkreatifitas dan mengembangkan potensi yang ada.

\section{b. Di dalam Keluarga.}

Keberadaan lanjut usia di dalam keluargaadalah motivator dan penasihat. Sebagai motivator, keluarga dapat belajar dari pengalaman lanjut usia tentang sistem kehidupan rumah tangga yang sesuai dengan kehendak Tuhan. Sebagai penasihat, lanjut usia telah lebih dulu "tahu" akan pengalaman hidup, maka mereka mengajarkan pengalaman mereka melalui pengalaman hidup. Lanjut usia dapat memamfaatkan masa tuanya memberikan kepemimpinan dengan membangun kebersamaan keluarga. 


\section{c. Di dalam Masyarakat.}

Kedudukan lanjut usia di dalam masyarakat biasanya tergantung dalam satu kultural masyarakat. Bagi masyarakat Batak misalnya, orang lanjut usia dituakan dan dihormati. Keberadaan mereka dianggap sebagai sumber berkat, sumber nasihat dan berperan sebagai pengambil keputusan.

\section{Lanjut Usia dalam Pandangan Alkitab.}

\section{Lanjut Usia dalam Perjanjian Lama.}

Alkitab memandang usia tua sebagai periode kehidupan di mana seseorang telah "beranjak jauh" dari periode terdahulu yang lebih menyenangkan atau yang penuh dengan manfaat (Sibuea, 2014). Mencapai usia lanjut sangat diinginkan dan dipandang sebagai hadiah untuk kesalehan dan tanda karunia dari Tuhan (Kejadian 15: 15; Keluaran 20: 12). Bahkan masyarakat digambarkan sebagai masyarakat yang penuh berkat bila dalam masyarakat tersebut banyak orang yang lanjut usia (Yesaya 65: 20; Zakaria 8; 4). Menghormati lanjut usia sebagai orang tua merupakan kewajiban. Setiap orang harus memberikan tempat kepada orang tua, baik dari kaum keluarga maupun dari luar, jika dia mau duduk atau berbaring (Paterson, 1997). Dalam cerita Alkitab dijelaskan bahwa kekejaman orang Kasdim dilukiskan terkait dengan sikap mereka yang tidak menaruh belas kasihan kepada orang tua atau orang ubanan (2 Tawarikh 36: 17). Berarti setiap orang harus menghormati, memperhatikan dan mengasihi orang lanjut usia. Bahkan gereja mesti berperan pula melayani satu sama lain sebagai satu keluarga tanpa membedakan usia (Roma 12: 4 - 5; Markus 3: 35). Keluarga bukan sebagai koleksi individu-individu, tetapi suatu organisme, satu tubuh (bnd. 1 Korintus 12), sehingga Allah dimuliakan dalam segala hal melalui Yesus Kristus (bnd. 1 Petrus 4: 10 - 11). Semua ini menegaskan betapa Alkitab memandang positif lanjut usia.

Lanjut usia adalah berkat dan kemurahan Allah. Banyak ayat dalam Perjanjian Lama yang bersangkut-paut dengan lanjut usia, misalnya: "Dalam usia tinggi engkau akan turun ke dalam kubur..." (Ayub 5: 26), "janganlah membuang aku pada masa tuaku, janganlah, meninggalkan aku apabila kekuatanku habis" (Mazmur 71: 9). "Masa hidup kami tujuh puluh tahun, dan jika kami kuat, delapan puluh tahun..." (Mazmur 90: 10), "pada masa tuapun mereka masih berbuah..." (Mazmur 92: 15). "Karena panjang umur dan lanjut usia serta sejahtera akan ditambahkannya kepadamu" (Amsal 3: 2). "Sampai masa tuamu Aku tetap Dia dan sampai masa putih rambutmu aku menggendong kamu..." (Yesaya 46: 4). Ayat-ayat ini menunjukkan bahwa Tuhan 
memberkati manusia dengan panjang umur dan memberi hikmat kepada orang-orang yang lanjut usia.

\section{Lanjut Usia dalam Perjanjian Baru}

Dalam Perjanjian Baru, lanjut usia digambarkan sebagai orang-orang yang harus dihormati dan mereka juga harus memberi teladan kepada orang-orang muda (1 Timotius $5: 1$, 4; Efesus $3: 20$; Titus $2: 1$ - 3) (Friedrich, n.d.). Petunjuk paling kuat terhadap lanjut usia terdapat dalam Injil Lukas yang memberikan gambaran mengenai martabat dan peran krusial pada lanjut usia dalam mengantisipasi serta membantu kehadiran Mesias yang telah dijanjikan. Pada masa tuanya, Zakaria dan istrinya Elisabeth, keduanya "adalah benar di hadapan Allah", artinya mereka hidup dan berkelakuan sesuai dengan kehendak Allah, dengan jalan menaati perintah dan ketetaapan Tuhan secara sempurna (bnd.Filipi $3: 6 b$ ). Zakaria sebagai seorang imam setia melakukan tugasnya sampai lanjut usia. Lanjut usia tidak menjadi penghalang dalam pelayanan sebagai imam. Namun demikian dalam hidup mereka sampai masa tuanya ada sesuatu yang menyedihkan, mereka belum mendapatkan anak (Boland, 1999). Seperti yang dikatakan malaikat Tuhan kepadanya, Zakaria dan istrinya Elisabeth mendapatkan seorang anak yang ditentukan menjadi "suara yang berseruseru di padang gurun" (Lukas $1: 13: 3: 4)$.

Ayat-ayat Alkitab dalam Perjanjian Baru mengajarkan supaya menghormati ayah dan ibu serta orang yang lanjut usia. Yesus menegur orang-orang Farisi dan Ahli Taurat untuk menjalankan perintah Allah dengan menghormati ayah dan ibu (Matius 15: 1 - 5; Makus $7: 1$ - 8). Di dalam menggembalakan jemaat, Paulus menasihati Timotius untuk menghargai, dan memperlakukan penuh hormat serta menegur orang yang tua sebagai bapa atau ibu ( 1 Timotius $5: 1-2$ ). Karena di dalam Kristus semua warga jemaat adalah satu keluarga (Budiman, 1997). Dalam hubungan antara orang tua dan anak-anak Rasul Paulus menasihati jemaat orang-orang muda di Efesus supaya taat dan menghormati orang tua di dalam Tuhan. (Efesus 6: 1 - 4; Kolose 3: 20 -21). Menurut Paulus, taat dan menghormati orang tua adalah keharusan, sesuatu yang benar dan adil bagi Allah. Sebab di dalam Kristus, Allah menyatakan kasih-Nya kepada orang tua, dan di dalam Dia, la memberikan kepada mereka suatu tempat terhormat (Abineno, 1997). Rasul Petrus menasihati orang-orang muda dan bawahan untuk tunduk kepada orang-orang yang tua (1 Petrus $5: 5$ ). 


\section{Pendampingan Pastoral kepada Lanjut Usia}

\section{Sekilas Tentang Pelayanan Lanjut Usia di Gereja HKBP Letare Ciledug.}

Gereja HKBP Letare Ciledug, menurut data statistik jemaat tahun 2019 beranggotakan 154 kepala keluarga dengan 597 jiwa yang terdiri dari:

- Kaum Bapak 136 jiwa

- Kaum lbu 154 jiwa

- Pemuda 190 jiwa

- Anak-anak 117 jiwa

- Lanjut Usia 81 jiwa

Dari 81 orang lanjut usia di antaranya adalah orang lanjut usia dari umur 60 tahun s/d umur 74 tahun; ada 72 orang, dari umur 75 tahun s/d 90 tahun; ada 9 orang. Dari jumlah anggota jemaat HKBP Letare kaum bapak dan kaum ibu 35\% diantaranya anggota jemaat yang berusia lanjut. Seksi Lanjut Usia baru terbentuk pada bulan Januari 2019 yang diputuskan dalam rapat jemaat, dengan program yang pertama adalah mengadakan ibadah Penelaahan Alkitab dan latihan koor lansia dua kali setiap bulan pada hari Senin di minggu pertama dan minggu ketiga. Jumlah yang mengikuti ibadah dan PA rata-rata 20 orang, masih sangat sedikit dibandingkan jumlah keseluruhan lanjut usia di HKBP Letare. Secara umum program pelayanan gereja yang selama ini diikuti lanjut usia adalah: Kebaktian Minggu, Kebaktian Keluarga, Penelaahan Alkitab, latihan koor dan kebaktian penghiburan.

Disela-sela ibadah dan PA kita mendengar bahwa begitu banyak pergumulan hidup yang mereka alami sebagai orang lanjut usia. Persoalan keluarga, anak-anak, tenaga yang sudah mulai berkurang, sakit penyakit, masalah ekonomi/pekerjaan, dan bahkan kerinduan untuk ikut beribadah dan PA. Karena itu memasuki tahun kedua, seksi lansia HKBP Letare menambah program pelayanan dengan mengadakan perkunjungan ke rumah sesama lanjut usia, dengan tujuan berbagi rasa, saling mendoakan dan menguatkan di tengah-tengah pergumulan yang mereka hadapi.Selanjutnya setelah program ini kita akan mengadakan pelayan pastoral berbasis kelompok untuk mempererat tali persaudaraan di antara lanjut usia sekaligus untuk dapat berbagi rasa atas segala pergumulan yang mereka hadapi. Kiranya ke depan pelayanan Seksi Lansia HKBP Letare semakin berbuah dan semakin banyak jemaat lansia HKBP Letare yang mau mempersembahkan hidupnya kepada Tuhan melalui pelayanan seksi lanjut usia. 


\section{Kasus-kasus Lanjut Usia di HKBP Letare}

Saya melakukan penelitian kepada lima orang anggota jemaat lanjut usia mewakili dari 81 orang atau 35\% dari anggota jemaat yang sudah lanjut usia, dengan metode wawancara langsung. Lima orang yang dipilih laki-laki dengan melihat kasus-kasus yang mereka hadapi tanpa membedakan gender. Penelitian ini dilakukan setelah mendapat izin dari konseli, sehingga kerahasiaan pribadi dari setiap konseli terjaga dengan baik.

\section{Kasus 1:}

Bapak KP Umur 76 Tahun : Di masa tuanya harus membesarkan seorang cucu yang di tinggal mati anak menantunya. Disamping mengurus dan menyekolahkan cucunya bapak KP menderita gangguan kesehatan penyempitan pembuluh darah dan sekali sebulan harus kontrol ke rumah sakit. Dalam situasi yang dihadapinya bapak KP mengaku tidak dapat menjalani hari-hari tuanya dengan tenang sebagaimana orang lanjut usia pada umumnya.

\section{Kasus 2:}

Bapak PS Umur 74 Tahun : Hidupnya lebih banyak di kursi roda dan di tempat tidur. la merasa hidupnya tidak berguna kerena menjadi beban bagi keluarga dan anakanak. Sementara istri dan anak-anak bekerja, ia merasa kesepian dan tidak ada yang menemani dalam kesendirianya.

\section{Kasus 3:}

Bapak SMB Umur 74 Tahun : walaupun sudah tua tetapi masih bekerja di Perusahaan Swasta, motivator bagi anak-anaknya. la tidak bisa menikmati masa pensiunnya demi menjadi contoh bagi anak-anaknya sekalipun anak-anaknya sudah mandiri. Disamping itu dengan bekerja ia mengaku untuk menghindari diri dari kepikunan, karena belajar dari bosnya yang mengalami kepikunan setelah pensiun.

\section{Kasus 4:}

Bapak MM Umur 78 Tahun : Sakit-sakitan, dan tenaganya sudah lemah, dan tidak dapat beraktifitas lama. la juga bergumul akan anak-anaknya (tiga orang) sudah berumur di atas 40 tahun tetapi belum menikah. Bagi orang Batak situasi seperti itu merupakan suatu "cacat" di tengah masyarakat.

\section{Kasus 5:}

Bapak TSH Umur 74 Tahun, seorang pensiunan dair PU. Hidup berdua dengan istrinya, mereka tidak mempunyai keturunan, dan sakit-sakitan Penyakit yang dideritanya membuat tubuhnya kurus dan kelihatan lemah. Tidak ada keluarga yang 
merawat dan mengurus mereka. Hari-hari mereka dihabiskan dengan berobat rutin ke dokter setiap minggu. Pergumulan mereka ialah bagaimana kehidupan mereka ke depan menjalani hari tua tanpa bantuan orang lain.

\section{Rangkuman Kasus:}

Dari lima kasus di atas, penyakit yang mereka alami membuat mereka terbatas bergerak dan beraktivitas. Sementara ada pergumulan lain yaitu pergumulan lain tentang keberadaan keluarga dan anak-anak. Para lanjut usia akhirnya selalu menyadari kelemahan dan kekurangannya kepada Tuhan dan cenderung bersikap pasrah bahwa semuanya tergantung kepada Tuhan. Disinilah dibutuhkan kehadiran pendampingan pastoral untuk menopang dan memberdayakan mereka supaya dapat menerima dan memahami keberadaan mereka menjalani hari-hari tuanya.

\section{Pengertian dan Tujuan Pendampingan Pastoral}

Kata pendampingan pastoral adalah gabungan dua kata yang mempunyai makna pelayanan, yaitu kata "pendampingan" dan kata "pastoral". Kata pendampingan berasal dari kata kerja "mendampingi". Mendampingi merupakan suatu kegiatan menolong orang lain yang karena suatu sebab perlu di dampingi. Istilah pendampingan memiliki arti kegiatan kemitraan, bahu membahu, menemani, membagi/berbagi dengan tujuan saling menumbuhkan dan mengutuhkan.dalam arti yang luas mencakup pemberian nasihat dan bimbingan (Beek, 2010). Dengan kata lain, pendampingan pastoral adalah suatu upaya yang disengaja untuk memberi pertolongan kepada seseorang atau kelompok yang sedang mengalami masalah, agar masalah tersebut tidak mednjadi penghalang dalam pertumbuhan di berbagai segi kehidupan (Engel, 2016).

Istilah "pastoral' berasal dari "pastor" dalam bahasa Latin, yang artinya gembala. Pengistilahan ini dihubungkan dengan diri Yesus Kristus dan karya-Nya sebagai "Pastor Sejati” atau “Gembala Yang Baik' (Yohanes 10) (Beek, 2010). Menurut Abineno, kosakata pastoral dipakai dalam dua pengertian. Pertama, pastoral sebagai kata sifat dari pastor. Istilah pastoral dalam konteks ini berarti pengembalaan sesuai dengan tugas pastor. Kedua, pastoral sebagai studi tentang penggembalaan (Abineno, 1997).

Tujuan pendampingan pastoral yaitu mendampingi pasien dari segi spiritual dalam proses penyembuhan secara utuh (holistik). Kebutuhan holistik orang yang sedang sakit, ialah: fisik (membutuhkan istirahat, obat, diet tertentu), mental 
(membutuhkan kekuatan mental dalam mengatasi penderitaan), sosial (membutuhkan kehadiran orang lain sebagai teman yang dapat diajak berbagi rasa), rohani (membutuhkan peneguhan keyakinan akan kasih setia Tuhan atas dirinya).

\section{Fungsi Pendampingan Pastoral}

\section{a. Fungsi Menopang (Sustaining).}

Fungsi menopang(sustaining)menurut Hiltner merupakan pelayanan dukungan dan dorongan melalui "berada bersama dengan" (kehadiran) ketika keutuhan telah terpatahkan atau telah mengalami kerusakan dan tidak mampu untuk diperbaiki. Lanjut usia membutuhkan kehadiran orang lain bertujuan untuk membesarkan hati mereka agar teguh dalam situasi yang dihadapi. Karena itu, fungsi penopangan menurut Hiltner adalah aspek yang menekankan "berada bersama dengan" (Hiltner, 1958). Clebsch dan Jaekle mengatakan bahwa fungsi menopang terpokus untuk menolong yang sakit atau terluka agar dapat bertahan dan mengatasi keadaan yang dialami (Clebsch \& Jaekle, 1967). Mereka menyebutkan fungsi menopang meliputi empat aspek: Pertama, penjagaan (preservation), mendukung orang yang telah mengalami kehilangan agar tidak terlalu jauh tenggelam dalam kesedihan dan sebisa mungkin diatasi. Kedua, penghiburan (consolation) memberi dorongan (motivasi) dan semangat kepada orang lanjut usia sejauh mereka terbuka terhadap penghiburan. Ketiga, penguatan (consolidation) berusaha untuk mengarahkan dan menyusun kembali sisa tenaganya agar lanjut usia itu sendiri dapat menangani situasi tersebut. Keempat, pemulihan kembali (redemption), orang lanjut usia dapat menerima perubahan-perubahan dalam dirinya dan mulai membangun yang baru dan supaya dapat berpijak pada situasi yang baru ini.

Fungsi menopang, menurut Daniel Susanto bermanfaat dilakukan terhadap orang sakit yang secara medis tidak dapat disembuhkan lagi, orang yang berduka karena kematian, orang yang telah lama menderita. Dalam situasi ini, tanggapan konselor harus hanya terpokus pada masalah inti dan disampaikan dengan singkat dan tepat (Susanto, 2006). Karena konseli biasanya sangat sedih, maka kehadiran konselor secara rutin dan mengutamakan komunikasi non-lisan akan banyak menolong konseli, sebab biasanya konseli sangat gelisah.

Sasaran penopangan bagi para lanjut usia adalah penjagaan, penghiburan, penguatan hati serta pemulihan kembali kepribadian mereka. Dalam proses itu, sustainer turut campur menolong, seperti ahli bedah yang tidak hanya mengajar pasien menggunakan sesuatu hingga luka menjadi sembuh. Kesuksesan sustaining bukanlah dengan memberikan sesuatu, seperti kekuatan, melainkan menolong lanjut 
usia mengangkat (to draw upon) sumber-sumber kekuatannya yang potensial dan bermamfaat bagi dia (Hiltner, 1958).

Dalam kasus 1 bapak KP dan istri yang hidup bersama cucu satu-satunya tetap mengalami kesedihan yang mendalam mengingat masa depan cucunya yang sudah di tinggal mati oleh orangtuanya, satu-satunya anak dan mantu dari bapak KP. Bapak KP sudah tua dan sakit-sakitan sementara cucunya masih menempuh pendidikan. Dalam situasi ini mereka butuh penopangan dan penghiburan supaya tetap semangat dan berpengharapan menyertai cucunya meraih cita-cita sebelum Tuhan memangilnya.

Dalam kasus 2 bapak PS berharap lebih baik mati saja sebab ia sudah pasrah dan menyerahkan hidupnya pada Tuhan karena merasa hidupnya tidak berguna. Bapak PS butuh penopangan dan penguatan agar ia dapat menerima keberadaan yang dia alami dan dapat menjalani hari-harinya dengan sukacita dan berpengharapan.

Peranan gereja dan pendeta atau pelayan pastoral memang sangat dibutuhkan dan diharapkan dalam memberi dukungan, pengarahan dan penguatan pada saat lanjut usia menderita kehilangan atau dukacita, kelemahan, kegelisahan dan keputusasaan akibat penderitaan yang mereka hadapi.

\section{b. Fungsi Memelihara atau Memberdayakan (Nurturing).}

Fungsi memelihara atau memberdayakan (nurturing) menurut Howard Clinebell, Art van Beek dan Daniel Susanto, adalah menolong dan memampukan konseli mengembangkan potensi-potensi yang diberikan Allah kepadanya untuk mengatasi masalah yang dihadapinya. Konselor menolong konseli untuk mengenali potensi apa saja yang ada di dalam dirinya dan potensi itu digunakan dalam melanjutkan kehidupannya. Pendampingan pastoral akan menjadi lebih efektif bila lanjut usia dilibatkan secara aktif dalam rangka memobilisasi sumber data yang ada dalam dirinya demi mengatasi masalahnya dan mendorong pertumbuhannya pada masa tuanya (Clinebell, 1992).

Fungsi memelihara atau memerdayakan bagi lanjut usia adalah menolong dan memampukan mereka untuk menggunakan energi yang ada dalam diri mereka, memobilisasi potensi maupun pengalaman, hikmat kebijaksanaan maupun keteladanan lain yang mereka miliki. Fungsi ini juga menolong para lanjut usia untuk memelihara serta mengembangkan kreativitas mereka. Dalam mengimplementasikan fungsi memelihara atau mengasuh, pelayanan pastoral berusaha memotivasi lanjut 
usia agar menjadi lebih dewasa menghadapi masalah-masalah hidup. Pelayan pastoral berusaha memperkuat lanjut usia untuk menolong dirinya sendiri kepada kehidupan yang lebih baik.

Fungsi ini mengandaikan bahwa hidup manusia terus bertumbuh dan berkembang. Karena itu fungsi pemeliharaan dibutuhkan sebagai upaya pertolongan kepada manusia dalam arti bersama-sama menemukan potensi-potensi yang ada dan mengembangkan potensi itu, agar hidup terus berkembang dan bertumbuh. Pemerdayaan itu memungkinkan lanjut usia dengan potensi yang ada menolong dirinya sendiri dalam menghadapi kehidupan ini dengan berbagai liku-likunya, sehingga mereka bangkit membangun hidupnya yang baru dan menerima dengan senang hati segala permasalahan yang timbul.

\section{Pelayanan Pendampingan Pastoral Lanjut Usia Berbasis Kelompok.}

Di bawah ini saya menawarkan bentuk pelayanan pastoral kepada lanjut usia, di gereja HKBP Letare Ciledug Banten, yaitu melakukan pendampingan pastoral berbasis kelompok.Melalui bentuk pelayanan pastoral berbasis kelompok gereja dalam pelayanannya dapat menghadirkan pelayanan yang menopang dan memberdayakan kepada lanjut usia. Di mana di dalam pendampingan pastoral berbasis kelompok ini, sesama lanjut usia yang mengalami pergumulan yang sama, juga dapat saling berbagi, saling membantu/menolong dan menopang sesama yang sedang berada di dalam krisis dengan tindakan yang nyata sehingga mereka dapat melanjutkan perjalanan mereka yang sulit itu. Pendampingan pastoral berbasis kelompok bermanfaat untuk mengenal kondisi umat lebih tepat dan mendalam, pelayanan umat menjadi lebih efektif dan efisien, serta keterlibatan umat lebih meningkat. Di samping itu juga menjadi upaya nyata pemberdayaan umat sehingga bisa terwujud suatu persekutuan yang hidup dan dewasa dalam menghadirkan kerajaan Allah. Melalui pendampingan pastoral kelompok diharapkan anggota jemaat lanjut usia dapat terlibat dan melihat situasi dan kondisi yang nyata yang mereka hadapi sehingga dapat mewujudkan karya penggembalaan di dalam gereja dan di tengah masyarakat, serta membangun iman mereka melalui persekutuan, pelayanan firman, Sakramen, khotbah dan ibadah.

Pendampingan pastoral berbasis kelompok ini bersumber pada pengajaran Tuhan Yesus, yang telah memberikan teladan kepada gereja yang diawali dengan panggilan dan perutusan-Nya kepada murid-murid-Nya (bnd. Matius 28 : 19 - 20). Panggilan dan perutusan Yesus tidak berhenti untuk para murid saja tetapi juga 
ditujukan kepada umat beriman di zaman sekarang dan yang akan datang untuk pergi dan menjadikan semua bangsa menjadi murid Yesus, baik secara individu maupun secara kelompok. Para pengikut Yesus berkumpul bersama dalam kelompok kecil, untuk mendengarkan sabda, berdoa, bersahabat, berbagi dan menjangkau masyarakat. Kisah Para Rasul mencatat dampak dan dinamika kelompok-kelompok kecil ini dan pengalaman mereka bersama Kristus (Kisah Para Rasul 2 : 41 - 46; 4 : $32-37)$.

Howard John Clinebell, dalam bukunya Tipe-Tipe Dasar Pendampingan dan Konseling Pastoral, Bab XIV; Pendampingan dan Konseling Kelompok, menawarkan pendampingan pastoral kelompok sangat tepat dilakukan dalam pelayanan gereja. Clinebell menjelaskan bahwa pendekatan kelompok yang menerapkan pemahaman yang luas tentang krisis dan masalah kehidupan dapat membuat gereja semakin bertambah kuat untuk mencegah masalah kepribadian, yakni dengan merangsang pertumbuhan ke arah keutuhan (Clinebell, 1992). Di dalam kelompok para anggota dapat saling berbagi rasa. Setiap anggota mempunyai kesempatan untuk mengalami rasa terhisap yang memelihara kehangatan jiwanya. Di dalam kelompok, mereka ikut serta dalam penelaahan Alkitab, doa, pendampingan timbal balik dan juga pelayanan masayarakat.

Manfaat dari pendampingan pastoral berbasis kelompok:

- Psikiater Jerome D. Franks mengatakan: berbagi rasa, ide dan pengalaman secara intim dalam suatu suasana yang saling menghormati dan mengerti, pada gilirannya akan meningkatkan harga diri, memperdalam pengertian tentang diri sendiri dan membantu seseorang hidup berdampingan dengan orang lain.

- Pemanfaatan waktu dari seorang pendeta atau pemimpin dari kalangan warga untuk membantu lima hingga sepuluh orang secara serentak, lebih baik daripada menggunakan waktu yang sama untuk seorang saja.

- Kelompok itu membiarkan para penolong untuk menolong diri mereka sendiri dengan cara saling menolong, artinya adanya hubungan yang saling memberi.

Melalui pendampingan pastoral berbasis kelompok, diharapkan para lanjut usia dapat berbagi rasa, berbagi pengalaman dan berbagi masalah dalam kehidupan sehingga melalui pendampingan pelayanan berbasis kelompok mereka saling menopang, saling 
menghibur, saling menguatkan dan diberdayakan untuk mengalami pertumbuhan dan kesembuhan.

Bentuk Pendampingan pastoral berbasis kelompok melakukan kegiatan berupa:

a. Ibadah persekutuan kelompok, di dalamnya berisi pujian dan penyembahan, pelayanan firman,dan Sakramen, khotbah dan doa.

b. Sharing pengalaman anggota kelompok

a. Ibadah Persekutuan.

Pelayanan ibadah persekutuan lanjut usia dilakukan dua kali dalam sebulan,setiap hari Senin minggu pertama dan ketiga. Ibadah persekutuan ini memberikan dampak yang baik bagi lanjut usia untuk menumbuhkan pengalaman spiritual mereka, sekaligus membina kedekatan dengan Tuhannya. Ibadah persekutuan lanjut usia berisi:

- Pujian dan penyembahan.

Pujian dan penyembahan dalam bentuk nyanyian, doa dan ucapan syukur akan mengalir sebagai penyembahan dari hati yang murni dan tulus. Melalui pujian dan penyembahan kita dapat memusatkan hati dan pikiran kita kepada Tuhan, sehingga kita dapat mengalami kehadiran Tuhan dan akan semakin bertumbuh dalam hal-hal rohani (Warren \& Myers, 1996). Dengan pujian dan penyembahan diharapkan lanjut usia dapat dengan rutin menjalin persekutuan dengan Tuhan sebagai bagian dari rutinitas kehidupan menjalani masa lanjut usia.

- Pelayanan Firman dan Sakramen.

Pelayanan Firman dan Sakramen adalah pelayanan utama bagi lanjut usia. Mereka lebih daripada kelompok umur lainnya, butuh mendengar firman Tuhan secara objektif, seperti misalnya tema tentang pandangan Alkitab tentang pensiun sebagai berkat, kesepian, lanjut usia sebagai teladan hikmat, pengharapan, perasaan termarginalkan serta berkurangnya hubungan yang produktif. Lanjut usia memaknai Firman dan Sakramen sebagai personal grace. Mereka percaya bahwa berkat dan janji keselamatan itu juga dimaksdukan bagi mereka pada masa tua mereka. melalui pelayanan Firman dan Sakramen mereka dapat mengatasi sendiri rasa takut ditinggalkan dalam berbagai bentuk. Pelayanan Firman merupakan pelayanan pastoral yang benar-benar menjadi bentuk presensia, 
aktivitas Allah yang menyelamatkan, pengampunan dosa sekaligus membangkitkan lanjut usia dari erosi pengharapan.

Penerimaan sakramen menyatakan jaminan bahwa anugerah penebusan dari Allah tetap ada dan berlaku dan selalu akan berlaku bagi mereka (Abineno, 2007). Sakramen dilihat dalam dimensi transenden (2 Korintus $5: 20$ ) sebagai bukti dari anugerah Allah yang berkelanjutan, sekaligus merupakan jaminan kehidupan akan anugerah, bahwa Allah tidak akan meninggalkan mereka sendirian, dan tidak akan membuang mereka pada masa tua mereka (Mazmur 71 : 9) (Becker, 1986). Sakramen Perjamuan Kudus bagi gereja HKBP adalah pesta sukacita bagi orang yang ikut, karena itu adalah pendahuluan dari persekutuan yang kekal. Itu juga adalah tanda syukur mengingat penebusan Tuhan Yesus dan jalan menerima kasih karunia-Nya (Matius $26: 20$ - 30; Markus $14: 17$ - 26; Lukas $22: 14-20 ; 1$ Korintus $11: 17-34$ ) (Napitupulu, n.d.).

\section{- Khotbah, dan Doa Pastoral.}

Khotbah dan unsur lain dalam ibadah menjadi bagian pelayanan pastoral pada lanjut usia. Para lanjut usia mendengar pemberitaan firman sekaligus meresponsnya dengan iman yang tulus dan murni, akan menolong mereka menghadapi masalah kehidupannya. Mereka akan menemukan bahwa Allah turut bekerja menguatkan mereka dalam kehidupan mereka sehari-hari. Alkitab adalah sumber kebenaran, sehingga Alkitab Firman Allah dapat memberi pertolongan. Khotbah pastoral adalah khotbah yang Alkitabiah. Injil adalah kekuatan allah untuk membawa keselamatan bagi setiap orang yang percaya. Di sinilah letak sentral khotbah bagi para lanjut usia (Roma $10: 14$-15), meskipun gereja harus tetap sadar bahwa khotbah bukanlah keseluruhan pelayanan (Keck, 1983).

Doa pastoral (the pastoral prayer) juga merupakan hal penting dalam pelayanan pastoral lanjut usia. Doa sebagai komunikasi langsung dengan Allah merupakan jantung ibadah. Doa menolong lanjut usia untk memersiapkan diri mendengarkan firman Tuhan. Doa dapat juga mengangkat pergumulan mereka sebagai lanjut usia (Galli, 1992). Doa adalah salah satu sumber religius yasng difokuskan dalam memasuki realitas transendental, yang dimaksudkan sebagai aksi partisipatif terhadap pergumulan hidup dan derita yang dialami oleh lanjut usia, sekaligus sebagai tanda penerimaan mereka akan transendensitas Allah (Thayer, n.d.). Doa merupakan penyerahan diri total di dalam iman dan pengakuan bahwa Allah hadir dan bekerja di 
dalam hidup dan pergumulan lanjut usia menyertai, menopang dan memampukan mereka menjalani kehidupan di hari tua.

Khotbah, doa dan ibadah adalah kekuatan yang hidup bagi lanjut usia untuk menjalani sisa hidup di hari tua. Diharapkan melalui khotbah, doa dan ibadah para lanjut usia semakin dapat meningkatkan kwalitas hidup mereka. Rajin beribadah, berdoa dan membaca firman membuat lanjut usia tidak mudah pikun (pengakuan bapak SMB dalam kasus 3).

\section{b. Sharing pengalaman anggota kelompok.}

Dalam sharing pengalaman ini para lanjut usia dipersiapkan untuk menghadapi berbagai macam krisis yang terjadi, baik fisik, mental, spiritualitas, psikis dan krisis sosial. Dengan memahami situasi dan kondisi yang dialami lanjut usia, di dalam kelompok mereka dapat berbagi dan bertukar pengalaman, saling menanggapi, dan memberi pertanyaan di antara sesama mereka. Dengan sharing pengalaman, masingmasing anggota kelompok berusaha memahami dan merasakan apa yang dialami dan dirasakan oleh anggota yang lainnya. Dengan demikian, untuk menopang dan memerdayakan lanjut usia di dalam pergumulan dan pengalaman hidup mereka, gereja/pelayan dapat memberikan pelayanan yang tepat dan optimal bagi mereka.

\section{KESIMPULAN}

Pendampingan pastoral yang relevan untuk lanjut usia adalah pendampingan pastoral yang bersifat menopang (sustaining) dan memelihara atau memberdayakan (nurturing). Fungsi menopang bertujuan untuk membesarkan hati orang lanjut usia agar teguh dalam situasi yang dihadapi sehingga lanjut usia dapat menerima hidupnya seperti apa adanya. Memelihara atau memerdayakan adalah menolong dan memampukan orang lanjut usia mengembangkan potensi-potensi yang ada padanya sebagai kekuatan yang dapat diandalkannya, untuk mengatasi masalah-masalah yang dihadapinya, sehingga mereka dapat melanjutkan kehidupannya.

Pendampingan pastoral yang bersifat menopang dan memberdayakan dapat dilakukan dalam bentuk pendampingan pastoral yang berbasis kelompok, dengan tujuan memelihara pertumbuhan dan menyembuhkan, memelihara kesatuan dan persekutuan. Pendekatan kelompok dapat memberikan kesempatan kepada lanjut usia untuk saling berbagi rasa, berbagi pengalaman melalui tanggapan dan pertanyaan, sehingga mereka dapat melihat keberadaan dan kondisi yang nyata yang mereka alami. Kondisi ini menimbulkan rasa kesatuan untuk saling menolong, saling menguatkan dan saling menopang, sehingga lanjut usia dapat menerima dan 
menjalani kehidupannya dengan baik. Metode pendampingan berbasis kelompok ini dibagi dalam dua bagian sesi yaitu: kelompok persekutuan lanjut usia yang diadakan sekali seminggu, dan kelompok persekutuan sharing (berkunjung kerumah lanjut usia) diadakan sekali dua minggu.

\section{DAFTAR PUSTAKA}

Abineno, J. L. C. (1997). Tafsiran Alkitab Surat Efesus. BPK Gunung Mulia.

Abineno, J. L. C. (2007). Pedoman Pastoral Kepada orang Berduka. BPK Gunung Mulia.

Becker, A. H. (1986). Ministry with Older Persons; A guide for Clergy and Congregations. Augsburg Publishing House.

Beek, A. Van. (2010). Pendampingan Pastoral. BPK Gunung Mulia.

Boland, B. J. (1999). Tafsiran Alkitab Injil Lukas. BPK Gunung Mulia.

Bons-Strom, M. (2015). Apakah Penggembalaan Itu? BPK Gunung Mulia.

Budiman, R. (1997). Tafsiran Alkitab Surat-Surat Pastoral I \& II Tinotius dan Titus. BPK Gunung Mulia.

Clebsch, W. A., \& Jaekle, C. R. (1967). Pastoral Care in Historical Persfective. Harper Torchbooks. Harper Torchbooks.

Clinebell, H. (1992). Basic Types of Pastoral Care and Counseling. Abingdon Press. Elizabeth, H. B. (1992). Psikologi Perkembangan. Erlangga.

Engel, J. D. (2016). Pastoral dan Kebutuhan Dasar Konseling. BPK Gunung Mulia. Friedrich, G. (Ed.). (n.d.). Theological Dictionary of The New Testament Vol. VI. Grand Rapids. WB Eerdmans.

Galli, M. (1992). The Pastoras/ Prayer (J. D. Berkley (Ed.)). WB Eerdmans. Hiltner, S. (1958). Preface to Pastoral Theology. Abingdon Press.

Keck, L. E. (1983). Toward a Theology of Rhetoric/Preaching. Harper Torchbooks. Napitupulu, B. (n.d.). Beberapa Catatan Tentang Beberapa Topik Pemahaman

Teologi HKBP. Kantor Pusat HKBP.

Paterson, R. M. (1997). Tafsiran Alkitab Kitab Imamat. BPK Gunung Mulia.

Santoso, H., \& Ismail, A. (2016). Memahami Krisis Lanjut Usia. BPK Gunung Mulia.

Sibuea, D. F. (2014). Percakapan Dengan Lanjut Usia; Suatu Bentuk Konseling Pastoral yang Relevan di Jemaat. LAPIK.

Susanto, D. (2006). Pelayanan Pastoral di Indonesia Pada Masa Transisi, Orasi Dies Natalis ke 72 STT Jakarta. UPI STT Jakarta.

Thayer, N. S. T. (n.d.). Spiritual and Pastoral Care. Fortress Press. 
Warren, \& Myers, R. (1996). Puji Pujian Pintu Menuju Hadirat Tuhan. Literatur Baptis.

Williamson, J. (1987). Aging. The Crossroad Publishing Company. 